\title{
Constructing the problem of initial teacher education in Aotearoa New Zealand: policy formation and risk, 2010-2018
}

\author{
Alexandra C. Gunn and Helen Trevethan \\ University of Otago, Dunedin
}

This paper reports findings from an interpretive policy and discourse analysis of documents informing contemporary initial teacher education (ITE) policy development in Aotearoa New Zealand. The study first asks: what is the problem of teacher education as constituted in policy and associated documents in the period 2010-2018? We then compare the problems, suggested solutions, and recent evidence about the work of teacher education in New Zealand, to discuss the policy discourse, and theorise about the potential utility of solutions to address the problems raised. Our comparative analysis of the problems of ITE and proposed policy solutions with research evidence of teacher education work underscores the imperative of engagement with local and relevant evidence-based knowledge as a basis for informed policy decision making.

Keywords: Initial Teacher Education, Policy development

\section{Introduction}

Initial teacher education (ITE) as a problem has permeated education system policy discourse in Aotearoa New Zealand for many years, yet evidence of ITE quality and practice to substantiate the problem, from studies of teacher education work in Aotearoa New Zealand, is scarcely invoked alongside this. Our paper considers the warrants for recent ITE policy solutions by comparing evidence of ITE practice in Aotearoa with the policy claims made over the last decade. A key purpose of our study is to weigh the policy discourse against evidence of practice and to evaluate the extent to which suggested policy measures might be providing direction to the field.

Over the last ten or so years, suggestions of problems with ITE provision in Aotearoa have pervaded policy papers and discourse (Alcorn, 2014). Teacher workforce issues, declining numbers of applicants for teaching, a suggested lack of preparedness of graduate teachers, a proliferation of teacher education options, and concerns over poor and/or variable programme quality are often held up in the public domain as evidence of the system's failure. A desire to improve education system quality, including the quality of the teacher workforce through ITE, is routinely expressed. However, evidence of the failure of teacher education, from actual studies into the teacher education practice in this country, is slight. Recent empirical work has more often focussed on strategies of continuous improvement, matters of ITE curriculum relevance, and practice components of programme design (Grudnoff, Haigh, \& Mackisack, 2017; McDonald, 2018; Sewell, Hansen, \& Weir, 2017). Two relatively large multi-year projects have added insights into aspects of current ITE provision, strengths, issues, and future directions: an Auckland University project working with 
complexity theory, equity issues, and ITE (Cochrane-Smith, et al., 2016; Ell, et al., 2017) and The Work of Teacher Education-NZ study (Berg, Gunn, Hill, \& Haigh, 2016; Gunn, Berg, Haigh, \& Hill, 2016; Gunn, Hill, Berg, \& Haigh, 2016, forthcoming, [hereafter WoTE-NZ] ${ }^{1}$ ). A body of work is beginning to tackle broader issues of recent ITE practice and development. For example, the practicum, its assessment, and student teacher support are addressed (Aitken, Corkery, \& Jones, 2017; Aspden \& McLachlan, 2017). Issues of ITE design are considered in the contemporary literature as well (Bell, Robertson, \& Norsworthy, 2017; Cooper, Sexton, \& Gunn, 2017; Heng, Quinlivan, \& du Plessis, 2019). Smaller-scale studies into elements of practice and pedagogical technique continue to proliferate and add considerable value to the development of knowledge for teacher education practice (see, for example, Agnew \& Gunn, 2019 on health education, including within ITE; Felis-Anaya, Martos-Garcia, \& Devis-Devis, 2018 on physical education, including within ITE; and Trevethan, 2017 on student teacher mentoring).

Notwithstanding the relative dearth of application of locally produced evidence about the failures of ITE provision in Aotearoa New Zealand, the professional body for teachers, in responding to its legal mandate to review ITE and provide direction to the profession (Education Act NZ, s.382(1)a and f(a)), signalled in 2018 major changes to the ITE programme accreditation and approval system (Teaching Council New Zealand, 2018, hereafter TCNZ). The policy foreshadows changes that may see aspects of ITE shared more overtly between providers (of ITE) and the profession (early childhood education services and schools) that seek to improve and streamline ITE, and that specify certain forms of ITE assessment. We understand that such measures are positioned as efforts to ameliorate the risks of variable, poor quality, and insufficient ITE practice.

Comparative analysis of the policy problems and proposed solutions with research evidence of teacher education work underscores the imperative of engagement with local and relevant evidence-based knowledge as a basis for informed decision making. As teacher educators in the system, we, Alex and Helen, have vested interests in understanding the arguments and problems being posed about the work we do. We think there is merit in understanding the basis for current policy making as we make sense of the new environment within which we are being asked to work. Through such understanding we can commit to, and work with, the measures being asked.

\section{Context of ITE policy development in Aotearoa}

New Zealand's education system is once again involved in huge reform. Eighteen major education system review initiatives are underway across early childhood, learning support, curriculum, and assessment, including the very governance and management of schools and their funding. ITE is not immune and in fact, many of the initiatives and reports that have been promulgated in the last 18 months or so include recommendations for ITE improvement and reform. In some ways, it feels like teacher educators' work and teacher education have become a proverbial cork on the educational reform sea, thrown into policy debate, and upturned by new government initiatives, spanning for instance, programme trials of postgraduate entry to teaching through to the introduction of employment-based models in secondary schooling. Added to this context has been several years of changes to the

\footnotetext{
${ }^{1}$ The Work of Teacher Education - NZ was funded by the Teaching and Learning Research Initiative under grant 9142.
} 
professional body and development of a new set of teacher standards, all with implications for teacher education providers, curriculum, and outcomes. The last decade and a half has also seen most of ITE provision in Aotearoa New Zealand transition to the University sector. These changes have provided new opportunities and challenges.

One constant throughout this period has been that many different actors have repeatedly constituted our (teacher education) work as problematic in some way or another, claims that have been routinely reified in public and policy discourse. Therefore, we have taken this opportunity, now that policy solutions are proposed (Education Council, 2018, hereafter ECNZ; TCNZ, 2019), to take stock of the so-called problem of ITE, and to enquire into the warrants for change by examining the policy discourse with evidence from ITE practice.

Policy and document analysis are important research tools to help those who are impacted by change understand what is being asked of them and why. Tracing the provenance of new policy requirements can help give perspective to key agents of the proposed change - it can also provide affected parties with an account of the reality of the situation - tempering reaction and response. As we have already claimed, our work in ITE has been repeatedly constituted as troubling in one way or another. This study seeks to introduce evidence to the discourse in order to counteract the effects of populist claims and overabundant rhetoric. Our aim, as we investigate the questions - What is the problem of teacher education constituted in policy and associated documents in the period 2010-2018? What evidence for the problem(s) exists? And how does evidence of ITE practice in Aotearoa New Zealand reflect the problem(s) as constituted? - is to interrogate the warrant for change, gain perspective on it, and position ourselves and our work in relation to it so we can engage reasonably with the development of ITE in ways that build upon existing practice strengths. Next, we turn to an overview of the methods for our policy analysis research.

\section{Method}

Policy analysis is social and political activity, ultimately concerned with the conditions for living, recreation, health, work and social life that citizens will share (Bardoch, 2000). In the case of ITE, the policy remit is generally concerned with the production of highly qualified teachers and, as indicated later in this study's findings, teachers' longevity in the profession. However, the improvement of education systems through teacher performance and the system's ability to produce workers for an increasingly global market are all also important objectives of ITE system design and policy (OECD, 2005, 2012; Tatto, 2009).

An interpretive approach to policy analysis (which we took in this project) examines the way problems are framed and how that is reflected in policy (Browne, Coffey, Cook, Meiklejohn, \& Palermo, 2018). Interpretive policy analysis looks beneath the surface to the assumptions that underpin the policy problems, acknowledging that these are socially constructed. In our study of ITE policy and associated documents, we are interested in understanding both the problems of ITE that have been constituted in recent years, and their provenance.

We gathered 26 documents about ITE development and design from the Government and professional body for teachers that were dated from 2010 to 2018 . These included New Zealand Government working group reports, Ministry of Education (MoE) materials and initiatives concerning ITE, reports and policy documents from the professional body, and 
reports and correspondence between MoE officials and ITE providers concerning professional meetings and directions for ITE. Of the collection of the 26 documents, 20 spoke directly to problems within ITE; those documents were drawn upon as we informed our analysis (see Appendix 1).

We employed deductive and inductive readings of the documents looking for evidence of issues, concerns, and problems, before tracing the evolution of those ideas across the body of documents over time. First, we jointly produced three lists of categories of problems concerning ITE which, in our experience, were routinely alleged and remarked on in the ITE literature. One list pertained to ITE, a second to student teachers, a third, the profession. For example, the ITE categories included problems of 'insufficient practice opportunities', a 'theory/practice divide', and 'teacher educators as outdated'. The student teacher category noted issues such as, 'lack of preparedness', 'not disposed to teaching', and 'inability to cater for diversity'. The profession list included issues of 'low status', 'insufficient professional leadership', and 'lack of culturally responsive pedagogy'. Such categories were used deductively in our readings of the documents. As well as this, we read for new issues or problems we had failed to previously note, and where identified we included those and reread documents previously analysed deductively. While reading we were using the categories to ask: what are the problems of ITE constituted in policy? and subsequently to this, what evidence was provided to substantiate the problems posed? We also identified any overt statements of specific policy problems authors were seeking to address because we understood the documents were written or meetings held in response to a perceived need. Then, taking several of the problems that had been extensively argued within the policy sphere (as recognised by their frequency within the analysis we undertook) and considering the proposed solutions to those problems, we examined them in light of evidence about the work of teacher education in Aotearoa New Zealand generated from a local and recent study of ITE practice.

Next, we describe the basis of the ITE policy developments from the perspectives of Government (through the Ministry of Education) and the professional body, and identify the fuller scope of troubling practices as indicated in the policy and documents. Then we go on to explore two of these: the problem of the theory/practice divide, manifest in a sense that teacher educators and ITE providers are disconnected from practice settings, and the problem of outdated teacher education curriculum, manifest in the alleged inability of teacher educators to engage their students in evidence-based and transformative teaching practice. We selected these two problems because they represent one of the long-standing alleged problems of ITE, the disconnect of ITE from the profession (theory/practice divide), and a relatively newly established problem, the capacity of ITE to graduate evidencebased/informed and transformative teachers. Our interrogation of the policy problems rests largely upon evidence of teacher education practice from the WoTE-NZ study (Berg et al., 2016; Gunn, Berg et al., 2016; Gunn, Hill et al., 2016, forthcoming), although other local empirical works into teacher education practice are also entered into the discussion as appropriate.

\section{Findings}

From our policy analysis we found two major and parallel trajectories of concern about ITE raised by the New Zealand MoE and the teacher professional body (the TCNZ). The MoE 
recognised, at the end of the first decade of the $21^{\text {st }}$ century, that it needed to develop policy in a number of education related areas, including ITE. A final report to the Minister of Education by the Education Workforce Advisory Group (2010, hereafter EWAG) included a host of suggestions for change, including having a more profession-wide approach to ITE, improvements to the quality and relevance of ITE programmes, and measures to address teacher retention and supply. The professional body, on the other hand, raised issues of ITE being ill equipped to cope with so-called "future oriented" (ECNZ, 2016a) education needs, especially in relation to technological advancement, cultural diversity, and a then forthcoming change to professional standards for teaching. On face value these were sound policy concerns for the Government and professional body to be advancing. Governments need to be interested in education workforce supply issues and the quality of teacher education. The professional body is also mandated with exactly these kinds of concerns as part of its official remit. However, the proliferation of a whole host of additional issues is also evident in the documents, the accumulation of which affords an altogether alarming representation of the state of ITE.

The range of issues pervading the policy and public discourse is noted here: graduate variability, ITE students' dispositions to teach, the standard of literacy and numeracy competence of ITE graduates, confidence in teacher educators' capacity to assess professional practice; poor mentor teacher expertise; the disconnect between ITE and the professional field; and allegations of teacher educators' practices ill-equipping graduate teachers to practise in adaptive ways. Accordingly, we were concerned to understand the evidence upon which such claims of troubling ITE practice were being made. We scanned the documents again to see what local evidence of failed teacher education practice was being cited for the problems raised. The scan produced a list of 13 items from New Zealand ITE literature reviews and papers.

Arguably, there have not been many recently sustained and broadly based studies into teacher education practice in New Zealand besides those mentioned earlier and the WoTENZ study (which explored the material conditions and discursive construction of teacher education in the university sector, as well as student teacher learning). Many smaller scale empirical studies have been conducted and the Waikato Journal of Education (WJE) has taken a leading role in publishing articles on these through a series of special editions following Teacher Education Forum of Aotearoa New Zealand (TEFANZ) conferences and fora during the period concerned. The 2010 collection reported on issues of ITE design and practice (McGee \& Cooper, 2010), the 2013 special edition raised questions of ITE as a profession (O'Neill, Hansen, Rawlins, \& Donaldson, 2013), and in 2017 the very question of how best to educate a nation's teachers was the focus of the WJE special edition (Cooper, Sexton, \& Gunn, 2017) but we found little evidence of such works informing the debate.

Next we take the issues of a disconnect between ITE and the wider profession (theory/practice divide) and teacher educators' alleged inability to support graduates to be adaptive in practice, and consider how the framing of problems and subsequent policy developments might have been informed differently if New Zealand research and scholarship had been used to interrogate them. We draw from the aforementioned published and forthcoming WoTE-NZ findings to provide recent evidence of ITE practice. 


\section{A brief introduction to WoTE-NZ}

The WoTE-NZ) study was a 'two-year', two-phase project using tools of cultural historical activity theory (Engeström, 1999, 2001; Yamagata-Lynch, 2010) to study how teacher education was being constructed within universities and what teacher educators (TES) actually did at work. The study took place from October 2013 to December 2015, right in the middle of the policy debate and direction setting for ITE with which we are concerned. It also coincided with a trial postgraduate entry to initial teacher education experiment the MoE has been running, which started in 2013-14 and which will end mid-2020.

The WoTE-NZ work involved document and interview analysis in Phase One and workshadowing for a day, interviews, and a work-diary in Phase Two. An additional modified developmental work research change lab (Engeström, 2013; Virkkunen \& Newnham, 2013) was held with participant teacher educators once data from the field were beginning to be produced. This provided the research team and participants an opportunity to collectively interpret, debate, and discuss findings and implications of the WoTE-NZ research. The study provided evidence of what university-based ITE required of potential recruits to academic teacher education positions in universities, and it presented evidence of teacher educators' actual work through accounts of 14 days of actual work by TEs in the university system, plus their reports of their work through work diaries that recorded two sets of one-week's work, six months apart. A third element of the study concerned with student teacher learning contributed knowledge of teacher educators' teaching. As such the study provides close-up evidence of teaching methods and objectives motivating student teachers' and teacher educators' activities in ITE classrooms.

\section{The problem of a disconnect between ITE providers and the wider profession}

The first problem and risk within teacher education constituted in the policy and public discourse that we wished to interrogate was the perception that ITE provision is separated from the profession: a disconnect between ITE providers, schools, kura, and early childhood education settings exists (see Table 1). This concern was raised early in the discussions of ITE within the policies and documents we analysed, led initially by the MoE. However, the issue is advanced by the professional body also and plays out in calls for a more profession-wide approach to ITE that there be stronger links to practice within programmes, and improved connections, strengthened partnerships and the like. The risk is ITE that is too theorised and distant, far removed from the realities of real teaching which leads to graduates without the practical capability to teach (the so-called theory and practice divide that has long haunted ITE discourse, see for instance, Gravett, 2012; Korthagen, 2011). Partnership has subsequently become a major thrust of the new ITE approval requirement policies (TCNZ, 2019). 
Table 1

Examples of the framing of and solutions to the problem and risk of ITE disconnection from the profession

\begin{tabular}{|c|c|}
\hline Ministry of Education & Professional Body \\
\hline $\begin{array}{l}\text { "Improved links between providers, schools and } \\
\text { student teachers" (EWAG, 2010b, p.6) }\end{array}$ & $\begin{array}{l}\text { "We also want to consider ways to strengthen } \\
\text { partnerships between providers and schools, as well as } \\
\text { between associate/mentor teachers and teacher } \\
\text { educators" (ECNZ, 2016b, p. 4) }\end{array}$ \\
\hline $\begin{array}{l}\text { "A stronger link between ITE and classroom } \\
\text { practice is required to improve the quality and } \\
\text { retention of graduate teachers" (EWAG, 2010a, } \\
\text { p. 3) }\end{array}$ & $\begin{array}{l}\text { "Research into effective ITE also suggests that there are } \\
\text { more benefits from secure provider/school partnerships } \\
\text { that offer student teachers integration between different } \\
\text { kinds of expertise and learning opportunities" (ECNZ, } \\
\text { 2016b, p. 4) }\end{array}$ \\
\hline $\begin{array}{l}\text { [there is] broad support for the proposal to } \\
\text { improve connections between ITE providers, } \\
\text { trainee/beginning teachers and schools (EWAG, } \\
\text { 2011) }\end{array}$ & $\begin{array}{l}\text { "We talked about how to grow a strong partnership } \\
\text { between the profession and teacher education as being } \\
\text { important for providing confidence that graduates are } \\
\text { well prepared to teach in our future schools, kura and ECE } \\
\text { settings" (ECNZ, 2018b, p. 2) }\end{array}$ \\
\hline $\begin{array}{l}\text { "There appears to be a consensus that stronger } \\
\text { links between ITE and classroom practice has the } \\
\text { potential to improve the quality of graduate } \\
\text { teachers" (EWAG, 2011, p. 3) }\end{array}$ & $\begin{array}{l}\text { Requirements seek to strengthen ITE by formalising } \\
\text { "expectations for authentic partnerships with } \\
\text { schools/centres/kura/iwi" (ECNZ, 2018c, p. 2) }\end{array}$ \\
\hline
\end{tabular}

The calls for closer relationships between ITE and sites of professional practice are repeated in different ways, indicating that the problem of 'disconnect/insufficiently connected' and relatedly 'risk of poor/variable quality ITE' is being multiply construed. The MoE asserts that distributing responsibility for ITE across the profession, including after graduation, will result in better quality graduates and teachers, and improved retention rates. The professional body, on the other hand, calls for stronger partnerships between providers and schools (implying also kura and early childhood settings, we assume), and specifically mentions strengthening associate teacher and teacher educator relationships in order to give confidence in graduate preparation. The text presupposes that the current provision of ITE is inadequate in such ways. Turning to evidence of teacher education work, we set about testing this suggestion.

\section{How disconnected from the profession are ITE providers and teacher educators?}

The WoTE-NZ study provided plenty of evidence that much of the daily work of teacher education academics involved connecting with practice settings. The importance of teacher educators' connections with practice was evident in job recruitment documentation where a significant proportion of the work described was oriented towards the work in, and relationships with schools, kura, and early childhood settings. It required prospective teacher educators to, for instance, engage in student teacher visiting, remain active in curriculum subject associations, and build and maintain partnerships with sites of student teacher professional practice. Many of the TE positions interrogated in the WoTE-NZ study stipulated that applicants must retain their teacher registration credentials in order that they could discharge their work responsibilities, especially student teacher visiting. 
In Phase Two of the WoTE-NZ study, teacher education academics were workshadowed for a day. The data produced showed most of the teacher educators to be engaged in work related to teaching practice. For example, Cameron spent time with a colleague working on practicum related issues for a student, and Sam discussed practicum matters and student teachers' progress on practicum with others on two occasions during the day. Sam and Angel negotiated teaching practice visiting schedules for Sam who had 16 students to visit, assess, and guide through practicum in the coming weeks. Jessie booked cars for transport to $1^{\text {st }}$ and $2^{\text {nd }}$ year student teacher visiting that was upcoming, then Jessie completed practicum visits for two student teachers and met with them and their associate teachers to discuss progress. Jessie also visited a site of practice that was about to have student teachers for the first time, in order to build relationships and support associate teachers there with their future role. Brook invited a senior secondary school teacher to the university to upskill university academics in matters concerning NCEA and to discuss how the university academics' teaching might best support student teachers' learning in the curriculum domain concerned. And so on and so forth. The data illustrate that the teacher education academics' routine work activities regularly involved tasks within and related to sites of practice where their student teachers were learning. Another local study providing evidence of the ways ITE providers and partnering practice sites are regularly connected is Aitken, Corkery, and Jones' (2017) account of an ITE partnership in a small bachelor's programme. The programme was initiated at the request of local principals and relies heavily on close relationships between teachers in schools and teacher educators. Mentor teachers are integral to the partnership, commenting that "relationships, communication, commitment and collaboration" are essential to their work with the provider (p. 42). In both these cases, evidence of actual teacher educator and ITE provider work sits counterpoint to the policy assertion of disconnect between providers, teacher educators, and the wider profession. All ITE programmes are required to include a practicum for significant proportions of student teacher learning time. As the evidence cited here shows, practice-oriented work activities are a major domain of most teacher educators' everyday work.

\section{The problem of teacher educators' inability to support graduates to use evidence and to be adaptive in practice}

The second problem we set about interrogating from the policy and document analysis was a concern about the ability of graduate teachers to make evidence-informed teaching decisions and to develop adaptive expertise. The notion of adaptive expertise was entered into the broader discussion of New Zealand ITE through a paper commissioned by the MoE which fed into ITE sector discussions in the early phase of our policy analysis timeframe (Timperley, 2012, 2013). The paper presented several interrelated conceptions of student teacher expertise (novice, routine, and adaptive), arguing for ITE practices that would actively support adaptive expertise in graduate teachers. The paper identified education system problems that needed addressing, one of which was the prevalence of "transmission teaching" (Timperley, 2013 , p. 4). The problem had been reported in a publication from the Organisation for Economic Cooperation and Development, and was noted by Timperley as congruent with observations of teaching practice in two studies from New Zealand secondary schools from the previous decade. Teachers who engaged in transmission teaching methods were characterised as routine experts whose practice developed "a core set of skills and routines 
with greater fluency and efficiency" (p. 7) which were insufficient for meeting "the needs of under-served students, partly because it never invites teachers to question the efficacy of what they do" (p. 7).

The notion of adaptive expertise reflected Timperley's vision of teachers who were "driven by the moral imperative to promote the engagement, learning, and well-being of each of their students" $(2013$, p. 5). To become adaptive rather than routine, teachers needed to be able to recognise the assumptions underpinning their practice, to challenge those, and to use evidence, seek knowledge, innovate, and engage in ongoing inquiry to continually build professional knowledge about the effects of teaching on learners and learning. The calls for ITE programmes to develop adaptive expertise in graduates that were to follow, notably through the 2014-2020 trial of exemplary postgraduate entry to ITE (Ministry of Education, 2013), present a view of ITE practice as lacking in student teacher critical evaluation, devoid of opportunities for student teachers to produce and use evidence, interrogate assumptions, and to mobilise inquiry aimed at the learning interests and needs of their particular student groups. Table 2 presents evidence of this perceived problem and the associated risk of routine expertise through official calls for evidence of how future programmes of ITE will support the development of adaptive expertise in graduates.

Table 2

Examples of the calls for ITE to develop adaptive expert(ise) in graduates

\begin{tabular}{|c|c|}
\hline Ministry of Education & Professional Body \\
\hline $\begin{array}{l}\text { ITE providers who wish to submit an exemplary } \\
\text { programme must demonstrate how the programme } \\
\text { will enable a substantial shift in the nature and quality } \\
\text { of opportunities for ITE students to learn to practise } \\
\text { and to develop adaptive expertise (MOE, 2013, p. 2) }\end{array}$ & $\begin{array}{l}\text { A future-focussed ITE system "will need to provide } \\
\text { strong theoretical foundations and the skills required } \\
\text { to be an adaptive practitioner" (ECNZ, 2016a, p. 1) }\end{array}$ \\
\hline $\begin{array}{l}\text { "Teachers entering the profession need to have the } \\
\text { knowledge and adaptive expertise to work effectively } \\
\text { with an increasingly diverse student population } \\
\text { (MOE, 2013, p. 3) }\end{array}$ & $\begin{array}{l}\text { We believe our future teachers need the adaptive } \\
\text { expertise to apply information and research to } \\
\text { enhance their practice and in turn lift learner } \\
\text { achievement from when they begin teaching (ECNZ, } \\
\text { 2016b, p. 2) }\end{array}$ \\
\hline $\begin{array}{l}\text { Essential elements [of programme design include]... } \\
\text { how the programme will ... "combine learning to } \\
\text { teach with the professional knowledge base required } \\
\text { to develop adaptive expertise (MOE, 2013, p. 4) }\end{array}$ & $\begin{array}{l}\text { "Approval requirements for programmes would } \\
\text { require all practica to demonstrate quality features } \\
\text { including ... student teachers are proactive in } \\
\text { developing adaptive expertise with support" (ECNZ, } \\
2017 \text { b, p. 7) }\end{array}$ \\
\hline $\begin{array}{l}\text { MOE-ITE Provider Hui (February 2016) notes the } \\
\text { current ITE provider research into: } \\
\text { - development of adaptive expertise, } \\
\text { - competence and adaptive expertise. }\end{array}$ & $\begin{array}{l}\text { We want all teachers to enter the profession with the } \\
\text { skills they need to be great teachers when they first } \\
\text { start teaching and to adapt their professional } \\
\text { practice. In particular we want all ITE programmes to } \\
\text { provide students with: adaptive expertise skills" } \\
\text { (ECNZ, 2017b, p. 5). }\end{array}$ \\
\hline
\end{tabular}

The Ministry of Education's uptake of Timperley's notion of adaptive expertise was swift and comprehensive. It found its way into the call for proposals for trials of so-called exemplary postgraduate ITE qualifications in 2013 and into the broader professional discourse quickly thereafter. Successful tenderers for the postgraduate trial programme would be accountable for evidencing how their programmes were developing adaptive expertise, and we see from 
Table 2 that providers invested research energy into this agenda as the programmes ran. The professional body then connected their vision for ITE with the notion of adaptive expertise and the concept wound its way into the ITE policy development (ECNZ, 2018).

Adaptive expertise can be interpreted in many ways. Central to understanding this term and its use in the Aotearoa New Zealand context, however, is to appreciate the emphasis placed on teachers (and student teachers) making pedagogical choices, informed by their knowledge of learners in context, including the ability to evaluate the impact of their teaching decisions and to learn from their experiences. As part of this process, Timperley (2013) underscored the need for teachers to practise metacognition and self-regulation in order to promote life-long learning and improve the effectiveness of what they do. Two teacher educators from the WoTENZ study, Riley and Cas, worked deliberately to scaffold the metacognitive and self-regulatory practices of students in their teaching. Riley, for instance, was teaching a senior music class. The class began with Riley introducing examples of nationally moderated music assessments to student teachers. With Riley's prompting, the class began discussing the interpretation and application of assessment criteria, and issues of assessment in general, with specific mention of criterion-referenced assessment. Riley used the assessment activity in class to not only have students interrogate their beliefs and preferences, language, interpretations and application of assessment criteria, but also to provoke students' learning about NCEA assessment tools and their role in supporting teacher decision making. Later, Riley used scenarios drawn from scholarship about music teaching to facilitate student discussion about effective and less effective pedagogical practices. Students were required to explain their thinking and were actively involved in reflecting on their experiences and reading with effective teaching as the focus. Riley reported that aims for the teaching session included "development of assessment capability and literacy, developing assessment out of holistic music programmes, assessment for learning, consciousness raising in decision making, and opening teaching up (through good assessment practice)" (Gunn et al., forthcoming). Through Riley's teaching, student teachers were becoming practised at verbalising factors that might influence their decision making as teachers and to consider how assessment information produced from teaching and learning situations could inform their future teaching.

In another case, Cas' teaching involved students working on a mathematics problemsolving activity. In the process, Cas was explicitly modelling aspects of effective pedagogy for mathematics teaching, selected because of the particular group of students in the class. The class was one involving students who intended to apply for ITE and who at the present time, were working on meeting entry level standards at their university. The students had been less successful in mathematics themselves in their own schooling journeys and were thus working to develop their mathematical expertise. Cas had specifically planned activities in which there was a focus on working collaboratively and having the students learn though discourse. In the post work-shadowing interview Cas challenged routine practice directly by asserting that students (like those in the class) needed opportunities to work together because many secondary school classrooms were very traditional and didn't provide students at school the chance to collaborate in mathematics. For Cas, traditional and individualised teaching could impede some learners' success and so to intervene in the students' historical pattern of underachievement in mathematics education Cas planned different teaching methods. Furthermore, the students were required to verbalise their thinking and work through processes of trial and error in their problem-solving strategies, learning from their mistakes and changing their responses to the activities as they went. Thus, they were becoming practised in self-regulated learning and articulating the reasoning behind their decision 
making as they worked together, both skills part of adaptive practice. Cas had planned teaching that reflected Timperley's view that responsive and adaptive teaching has the "engagement, learning, and well-being of all students" at its core (2013, p. 4).

Although we provide only two examples of evidence of ITE practice that contradict the persistent construction of teacher education programmes' insufficiency in supporting the development of adaptive expertise in graduates, other examples of locally produced and reported research that achieve the same are readily available. In the WJE volumes alone we see studies about how to shift conceptions of knowledge and curriculum within ITE at a time of curriculum reform (Andreotti, Fa'afoi, \& Giroux, 2010), teacher educators introducing specific pedagogical approaches to programmes in order to influence student teachers' learning (Paris, Polson-Genge, \& Shanks, 2010) and educators developing their assessment and moderation practices to improve ITE practice (Aspden \& McLachlan, 2017). These are examples of teacher education practice produced locally which might have been drawn into the policy discussions to inform policy makers and ground the debate in examples of real and recent New Zealand teacher education practice.

\section{What has our policy analysis taught us and how might we engage further with the development of ITE?}

As we noted at the outset of this article, a key purpose of our study was to weigh the policy discourse against evidence of practice and to evaluate the extent to which suggested policy measures might be providing direction to the field. As insiders to the policy measures being sought to advance the teaching profession we have been puzzling for a long time about the persistent construction of our work as troubling, and others' suggestions of what to do about it. Now that a direction is set, it has been timely to engage with the policy and public discourse in order to navigate ways ahead given what we know about aspects of existing teacher education work and practice.

In 2016, our teacher professional body said that there was little evidence about the effectiveness of ITE programmes to "provide strong theoretical foundations and the skills required to be an adaptive practitioner, offer rich practical experience that supports effective integration of theory and reality, and provide good understanding of day-to-day teaching practice" (ECNZ, 2016a, p. 1). An accumulation of public and policy discourse, substantiated through reference to two handfuls of literature review studies and commissioned reports, led to a picture of ITE practice riddled with problems, disconnected from the field, and outdated in its aims and pedagogical approaches. We have found here that the policy development has not been well informed by local, recent, empirical teacher education studies that might have contested some of the arguments laid out and which ended up leading the policy directions taken here.

We urge policy makers to more robustly test the warrant upon which their decisions are based. As we have seen here, the problem of 'disconnect' between the profession, teacher educators and ITE providers, and the failures of ITE to engage methods likely to support the development of adaptive expertise were neither borne out in the daily work lives of the teacher educators from the WoTE-NZ study nor elsewhere. Yet such elements of the discourse remain and have resulted in policy measures designed to make us do what many of us are already proficient at (partnership work, critical, evidence informed practice, for example). Nevertheless, work with the policies we must, and so we hope that through this policy analysis and comparison of policy problems with teacher education work we can take 
stock and garner considered responses to forthcoming change that will see teacher education academics, ITE providers, the professional body, and wider profession, not wholeheartedly disregard strengths of current practice in order to ease the burden of reform and improvement in the profession, of which we are all part.

\section{References}

Agnew, S., \& Gunn, A. C. (2019). Students' engagement with alternative constructions of menstruation. Health Education Journal, 78(6), 670-680.

Aitken, V., Corkery, F., \& Jones, K. (2017). Positions, storylines and speech acts: How five mentor teachers from EIT's Bachelor of Teaching (Primary) conceptualise their role in the partnership. Waikato Journal of Education, 22(3), 33-45.

Alcorn, N. (2014). Teacher education in New Zealand 1974-2014. Journal of Education for Teaching, 40(5), 447-460.

Andreotti, V., Fa'afoi, A., \& Giroux, M. (2010). Shifting conceptualisations of knowledge and learning in the implementation of the New Zealand curriculum: Conceptual models and a preliminary analysis of data. Waikato Journal of Education, 15(1), 29-48.

Aspden, K. M., \& McLachlan, C. (2017). A complex act: Teacher educators share their perspectives of practicum assessment. Waikato Journal of Education, 22(3), 21-32.

Bardoch, E. (2000). A practical guide for policy analysis: The eightfold path to more effective problem solving. New York: Chatham House.

Bell, C., Robertson, K., \& Norsworthy, B. (2017). Influential and intentional teacher education: Embodying a conceptual framework. Waikato Journal of Education, 22(3), 75-85.

Berg, D. A. G., Gunn, A. C., Hill, M. F., \& Haigh, M. (2016). Research in the work of New Zealand teacher educators: A CHAT perspective. Higher Education Research and Development, 35(6), 1125-1138 doi.10.1080/07294360.2016.1149694

Browne, J., Coffey, B., Cook, K., Meiklejohn, S., \& Palermo, C. (2018). A guide to policy analysis as a research method. Health Promotion International, 1-13. https://doiorg.ezproxy.otago.ac.nz/10.1093/heapro/day052

Cochran-Smith, M., Ell, F., Grudnoff, L., Haigh, M., Hill, M., \& Ludlow, L. (2016). Initial teacher education: What does it take to put equity at the centre? Teaching and Teacher Education, 57(1), 67-78.

Cooper, B., Sexton, S., \& Gunn, A. C. (2017). Introduction to the Special Issue: How to educate a nation's teachers. Debating quality initial teacher education for today and for the future. Waikato Journal of Education, 22(3), 3-7.

Education Act, NZ. (1989). Retrieved from http://www.legislation.govt.nz/act/public/1989/0080/latest/DLM175959.html

Education Council New Zealand, Matatū Aotearoa. (2016a). Strategic options for developing future oriented initial teacher education. Wellington: Author.

Education Council New Zealand, Matatū Aotearoa. (2016b). ECNZ Design Workshop discussion paper, November. Wellington: Author.

Education Council New Zealand, Matatū Aotearoa. (2017a). Future-focused ITE proposals: Summary of consultation findings. Wellington: Author.

Education Council New Zealand, Matatū Aotearoa. (2017b). Our vision. Wellington: Author. 
Education Council New Zealand, Matatū Aotearoa. (2018a). Initial teacher education programme approval requirements: Te tutukitanga o ngā paerewa mā tautoko. Stage One-Design (Draft). Wellington: Author.

Education Council of New Zealand, Matatū Aotearoa. (6 April, 2018b). Letter update re March ITEAG meeting.

Education Council of New Zealand, Matatū Aotearoa. (December, 2019c). ITE statement.

Education Workforce Advisory Group. (2010a). Education Workforce Advisory Group Discussion document. June 2010. Wellington: New Zealand Government.

Education Workforce Advisory Group. (2010b). Education Workforce Advisory Group report to the Minister of Education: Final report, April 2010. Wellington: NZ Government.

Education Workforce Advisory Group. (2011). Education Workforce Advisory Group: A vision for the teaching profession, April. Wellington: NZ Government.

Ell, F., Haigh, M., Cochran-Smith, M., Grudnoff, L., Ludlow, L., \& Hill, M. F. (2017). Mapping a complex system: What influences teacher learning during initial teacher education? Asia-Pacific Journal of Teacher Education, 45(4), 327-345.

Engeström, Y. (1999). Activity theory and individual and social transformation. In Y. Engeström, R. Miettinen \& R.-L. Punamäki (Eds), Perspectives on activity theory (pp. 19-38). Cambridge: Cambridge University Press.

Engeström, Y. (2001). Expansive learning at work: Toward an activity theoretical reconceptualization. Journal of Education and Work, 14(1), 133-156.

Engeström, Y. (2013). Foreword: Formative interventions for expansive learning. In J. Virkkunen \& S. Newnham (Eds.), The change laboratory: A tool for collaborative development of work and education (pp. xv-xviii). Rotterdam: Sense.

Felis-Anaya, M., Martos-Garcia, D., \& Devis-Devis, J. (2018). Socio-critical research on teaching physical education and physical education teacher education: A systematic review. European Physical Education Review, 24(3), 314-329.

Gravett, S. (2012). Crossing the "theory-practice divide": Learning to be(come) a teacher. South African Journal of Childhood Education, 2(2), 1-14.

Grudnoff, L., Haigh, M., \& Mackisack, V. (2017). Re-envisaging and reinvigorating schooluniversity practicum partnerships. Asia-Pacific Journal of Teacher Education, 45(2), 180-193.

Gunn, A. C., Berg, D., Haigh, M., \& Hill, M. (2016). Work of teacher educators: Teaching and learning in New Zealand university-based initial teacher education. Wellington, New Zealand: Teaching and Learning Research Initiative.

Gunn, A. C., Hill, M. F., Berg, D., \& Haigh, M. (2016). The changing work of teacher educators in Aotearoa New Zealand: A view through activity theory. Asia-Pacific Journal of Teacher Education, 44(4), 306-319. doi.10.1080/1359866X.2016.1174815

Gunn, A. C., Hill, M. F., Berg, D. A. G., \& Haigh, M. (Forthcoming). The promise and practice of university-based teacher education in Aotearoa New Zealand: Cultural historical insights into the work of teacher education. London: Bloomsbury.

Heng, L., Quinlivan, K., \& du Plessis, R. (2019). Exploring the creating of a new initial teacher education (ITE) programme underpinned by inclusion. International Journal of Inclusive Education, 23(10), 1017-1031.

Korthagen, F. A. J. (2011). Making teacher education relevant for practice: The pedagogy of realistic teacher education. Orbis Scholai, 5(2), 31-50. 
McDonald, L. (2018). Self-regulatory practices: Key aspects of learning for student teachers on practicum. In D. Heck \& A. Ambrosetti (Eds.), Teacher education in and for uncertain times (pp. 99-112). Singapore: Springer.

McGee, C., \& Cooper, B. (2010). Introduction to special edition. Waikato Journal of Education, 15(1), 3-7.

Ministry of Education. (2013). Request for application for provision of exemplary post graduate initial teacher education programmes. Wellington: NZ Government.

Ministry of Education and ITE sector hui. (2016, February). Agenda, papers and record of MOE and ITE sector hui, Wellington. In the possession of A. C. Gunn, University of Otago, Dunedin.

O’Neill, J., Hanson, S., Rawlins, P., \& Donaldson, J. (2013). Editorial introduction: Reclaiming and reframing a national voice for teacher education. Waikato Journal of Education, 18(1), 3-6.

Organisation for Economic Co-operation and Development. (2005). Teachers matter: Attracting, developing and retaining effective teachers. Paris: Author.

Organisation for Economic Co-operation and Development. (2012). Teacher education for diversity: Meeting the challenge. Paris: OECD Centre for Educational Research and Innovation.

Paris, J., Polson-Genge, A., \& Shanks, A. (2010). Effective pedagogy: The influence of teacher educators' practice on student teachers' practice and philosophy. Waikato Journal of Education, 15(1), 145-156.

Sewell, A., Hansen, S., \& Weir, K. (2017). Enhancing the capabilities of associate teachers in the practicum: A New Zealand case study. New Zealand Journal of Educational Studies, 52(1), 21-39.

Tatto, M. T. (2009). Teacher policy: A framework for comparative analysis. Prospects, 38, 487-508.

Teaching Council New Zealand, Matatū Aotearoa. (2018, December). ITE programme approval, monitoring and review requirements: Consultation feedback. Wellington, New Zealand: Author.

Teaching Council New Zealand, Matatū Aotearoa. (2019). ITE programme approval, monitoring and review requirements. Wellington, New Zealand: Author.

Timperley, H. (2012). Learning to practise: Draft paper for discussion and consultation. August 2012. Auckland, New Zealand: Faculty of Education, University of Auckland.

Timperley, H. (2013). Learning to practise: A paper for discussion. Wellington, New Zealand: Ministry of Education.

Trevethan, H. (2017). Educative mentors? The role of classroom teachers in initial teacher education: A New Zealand study. Journal of Education for Teaching: International Research and Pedagogy, 43(2), 219-231.

Virkkunen, J., \& Newnham, S. (2013). The change laboratory: A tool for collaborative development of work and education. Rotterdam: Sense.

Yamagata-Lynch, L. C. (2010). Activity systems analysis methods: Understanding complex learning environments. Springer Science+Business Media. 


\section{Appendix 1: List of ITE reports, announcements, documents, and policy pieces gathered for analysis.}

\begin{tabular}{|c|c|c|}
\hline 2010 & April & $\begin{array}{l}\text { *(1) Education Workforce Advisory Group Report to Minister of Education: Final } \\
\text { Report }\end{array}$ \\
\hline & June & *(2) Education Workforce Advisory Group: Discussion Document \\
\hline \multirow[t]{2}{*}{2011} & April & $\begin{array}{l}\text { *(3) Education Workforce Advisory group: A vision for the teaching profession - } \\
\text { Public Submission Report. }\end{array}$ \\
\hline & & $\begin{array}{l}\text { *(4) Information about attendance at MOE convened Education Workforce sector } \\
\text { forum on } 7 \text { and } 8 \text { April inclusive of (5) NZTC Paper to Minister's Teaching } \\
\text { Workforce Forum. }\end{array}$ \\
\hline \multirow[t]{5}{*}{2012} & August & *(6) Learning to practise- Draft for Discussion. Helen Timperley. \\
\hline & September & *(7) Letter to VC from Dep. Sec. MOE - post Budget, re PG ITE. \\
\hline & & *(8) MOE ITE workshops letters and paper providers. \\
\hline & & *(9) A vision for the teaching profession ITE briefing papers (Sept meeting) \\
\hline & & (10) ITE Education Outcomes Graduating Teacher Standards background paper \\
\hline 2013 & June & *(11) MOE request post graduate exemplary ITE RFP \\
\hline \multirow[t]{2}{*}{2014} & February & $\begin{array}{l}\text { *(12) Invitation to providers to attend April ITE sector, inclusive of forum agenda } \\
\text { and participants list. }\end{array}$ \\
\hline & November & $\begin{array}{l}\text { (13) Information re: ITE sector forums during August-Nov (inclusive of (14) Memo } \\
\text { from MOE ITE Manager about draft Terms of Reference for Inaugural MOE } \\
\text { initiated ITE Sector Forum) }\end{array}$ \\
\hline \multirow[t]{4}{*}{2016} & February & *(15) Notes of MOE ITE Sector Hui, Wellington \\
\hline & June & *(16) Education Council discussion document: Strategic options for ITE in NZ \\
\hline & November & *(17) Education Council ITE design workshops, Wellington and Auckland \\
\hline & December & *(18) Feedback summary from Education Council regarding ITE design workshops \\
\hline \multirow[t]{3}{*}{2017} & June & *(19) Future focussed ITE proposal and paper (ECNZ) \\
\hline & & $\begin{array}{l}\text { (20) ECNZ commissioned Whatman and MacDonald report: High quality practica } \\
\text { and the integration of theory and practice in ITE }\end{array}$ \\
\hline & & $\begin{array}{l}\text { (21) ECNZ commissioned Moltzen Report: Positioning teaching as a postgraduate } \\
\text { profession }\end{array}$ \\
\hline \multirow[t]{5}{*}{2018} & January & *(22) Education Council, our vision - ITE 2021 \\
\hline & February & $\begin{array}{l}\text { *(23) ECNZ Letter to providers regarding establishment of ITEAG and its first } \\
\text { meeting }\end{array}$ \\
\hline & April & *(24) ECNZ letter to providers about ITEAG's second meeting \\
\hline & July & *(25) ECNZ Draft ITE programme review and approval policy \\
\hline & December & *(26) ITE Statement from TCNZ \\
\hline
\end{tabular}

* Papers that, after analysis, contributed to the construction of the teacher education problem. 
Alexandra C. Gunn works at the University of Otago College of Education as an Associate Professor and Associate Dean. She conducts research and teaches in the areas of: early childhood education, inclusion, assessment, curriculum, teachers' beliefs and practices and the professional practices of teaching (teacher education).

Email: alex.gunn@otago.ac.nz

ORCID: http://orcid.org/0000-0002-8572-714X

Helen Trevethan is a Senior Lecturer at the University of Otago College of Education. She has a long history in initial teacher education and currently teaches in undergraduate and postgraduate teacher education programmes. Her main research interests are beginning teaching, mentoring and student teacher professional practice.

Email: helen.trevethan@otago.ac.nz

ORCID: http://orcid.org/0000-0003-1428-6620 